INOBIS: Jurnal Inovasi Bisnis dan Manajemen Indonesia

Volume 1, Nomor 4, September 2018

Gendut Sukarno; Kustini

\title{
Pemicu Kinerja Karyawan Perbankan Melalui Penguatan Knowledge Management Dan Budaya Kerja
}

\author{
Gendut Sukarno $^{1)}$ \\ Kustini $^{2)}$ \\ ${ }^{12)}$ Fakultas Ekonomi dan Bisnis UPN "Veteran" Jawa Timur \\ ${ }^{1)}$ sukarnogendut@yahoo.co.id \\ 2)kustini259@yahoo.co.id
}

\begin{abstract}
Abstrak
Penerapan knowledge managemenet di berbagai perusahan sepertinya sudah menjadi suatu kebutuhan mendasar pada era globalisasi saat ini. Kemampuan organisasi untuk mengelola knowledge yang ada merupakan kekuatan yang diperlukan untuk dapat tetap bertahan. Tujuan dari penelitian ini adalah untuk mengkaji konsep knowledge managemenet dan budaya kerja terhadap kinerja karyawan perbankan. Diharapkan kajian ini dapat bermanfaat bagi pengambil kebijakan terkait dengan bidang human resource didunia perbankan. Pupulasi dalam penelitian ini adalah seluruh karyawan PT. Bank BJ di Surabaya, adapaun sampel dalam penelitian ini adalah karyawan PT. Bank BJ sebanyak 47 responden sebagai sampel. Teknik analisis yang digunakan dalam penelitian ini menggunakan Partial Least Square (PLS). Berdasarkan hasil pengujian menemukan hasil bahwa, knowledge management mampu memberikan kontribusi yang sangat berarti terhadap kinerja karyawan PT. Bank BJ, sedangkan budaya kerja belum mampu memberikan kontribusi yang sangat berarti terhadap kinerja karyawan PT. Bank BJ.
\end{abstract}

Kata kunci : knowledge managemenet, budaya kerja.

\section{Pendahuluan}

\subsection{Latar Belakang}

Awan hitam nampaknya akan terus menaungi industri perbankan dalam negeri hingga akhir tahun. Usai pertumbuhan kredit diprediksi tidak akan mencapai dua digit tahun ini, isu efisiensi yang berujung pada pemangkasan pegawai perbankkan juga harus menerpa industri perbankkan yang saat ini merupkan bidang usaha sebagai penompang dalam akselerasi pertumbuhan industri. Sejumlah bank diketahui berencana melakukan efisiensi dalam menghadapai kompetisi yang kiat sengit. Aksi efisiensi itu pun membuat Serikat Pekerja di beberapa perbankkan merancang aksi unjuk rasa melakukan unjuk rasa atau demonstrasi.

Dunia kerja perbankkan sedang mengalami pergeseran besar-besaran. Teknologi mengubah cara bekerja, berkomunikasi, berhubungan, dan terutama, cara menjalani hidup. Fenomena yang terjadi, orang dapat bekerja bahkan sebelum dan setelah jam kerja sesungguhnya. Keseimbangan antara kehidupan kerja dan kehidupan pribadi sudah berbeda. Evolusi terinterkoneksi telah membuat urusan menangani manusia dan tenaga kerja menjadi tantangan besar dalam dunia bisnis. Dengan lebih dari 64\% CEO di Asia Pasifik mengkhawatirkan tersedianya sumber daya manusia (tenaga kerja) dengan kemampuan kunci, dan 63\% lainnya merasa mereka akan menghadapi kekurangan kemampuan internal dalam 3 sampai 5 tahun mendatang, hal ini berarti bagian sumber daya manusia (SDM) perusahaan memiliki tugas yang berat. 
INOBIS: Jurnal Inovasi Bisnis dan Manajemen Indonesia

Volume 1, Nomor 4, September 2018

Gendut Sukarno; Kustini

Pada era di mana tenaga kerja sudah memasuki dunia digital, maka Digital Human Resource (DHR) adalah cara bagian sumber daya manusia untuk bertahan dan bertransformasi untuk perusahaan. Tidak seperti yang dianggap kebanyakan orang, DHR bukan hanya melakukan otomatisasi proses ataupun digitalisasi.

Terkait dengan perubahan era jaman di atas, kemajuan dunia perbankkan tidak dapat dilepaskan dari kekayaan intelektual sumberdaya yang dimiliki. Pertumbuhan ekonomi kini tidak bisa lagi bertumpu pada faktor produksi berupa modal uang dan tanah, akan tetapi telah terjadi pergeseran dimana human capital menjadi faktor produksi kunci untuk mencapai pertumbuhan ekonomi yang berkelanjutan dan senjata bagi sebuah negara untuk memenangkan kompetisi global (competitive advantage of nation).

Sumberdaya yang dimiliki dunia perbankkan tidak hanya modal yang berwujud saja (tangible asset), namun juga modal tdiak berwujud (intangible asset). Modal yang tidak berwujud tersebut sering dinamakan Modal Intelektual atau Intellectual Capital. Sumber daya dimaksud harus dipelihara dan dikembangkan, melalui pengembangan dan pengelolaan pengetahuan (knowledge management). Mengelola aset intelektual dan asset pengetahuan (knowledge) perusahaan secara lebih efektif, serta mengeksploitasinya untuk meraih dan mempertahankan pangsa pasar, merupakan salah satu upaya dalam menciptakan sustainable competitive advantage.

Salah satu hal yang harus diperhatikan oleh perusahaan dalam mengelola fungsifungsi manajemen adalah bagaimana mengelola sumber daya manusia untuk dapat meningkatkan efisiensi dan efektivitas kerja. Knowledge management menjadi bidang penting dalam proses pembelajaran sebuah organisasi. Pengetahuan yang dimiliki oleh organisasi harus mampu memberikan kemajuan bagi organisasi itu sendiri. Untuk itu dibutuhkan manajemen pengetahuan (Knowledge management) yang kuat agar pengetahuan tersebut mengakar di setiap individu dalam organisasi.

Menyimak uraian di atas, akhir-akhir ini banyak organisasi yang telah menjadikan manajeman pengetahuan (knowledge management) sebagai salah satu strategi untuk menciptakan nilai, meningkatkan efektivitas dan produktifitas organisasi serta keunggulan kompetitif organisasi. Organisasi-organisasi mulai menerapkan manajemen pengetahuan sebagaimana halnya memperoleh pengetahuan, menyimpan pengetahuan, menerapkan pengetahuan, dan mendistribusikan pengetahuan. Terkait dengan pendistribusian pengetahuan ke sesama karyawan/ rekan kerja mempunyai prosentase yang cukup besar sekali, hal tersebut dilakukan sebagai upaya pengembangan pengetahuan dari karyawan ke karyawan lainnya. Kebiasaan mendistribusikan pengetahuan ini sangat tergantung juga dari budaya kerja yang ada dalam perusahaan tersebut. Budaya kerja yang kuat terutama terkait dengan budaya berbagi pengetahuan akan mempunyai dampak terhadap akselerasi kinerja karyawan. Dalam era disruption yaitu lingkungan yang sangat cepat berubah, pengetahuan akan mengalami keusangan oleh sebab itu perlu terus menerus diperbaharui melalui proses pembelajaran dan knowledge sharing.

Menurut Triguno (1997) budaya kerja adalah segala falsafah yang didasari oleh pandangan hidup sebagai nilai-nilai yang menjadi sifat, kebiasaan, dan kekuatan pendorong membudaya dalam suatu kelompok organisasi, kemudian tercermin dari sikap menjadi perilaku, kepercayaan, cita-cita, pendapat dan tindakan yang terwujud sebagai kerja atau bekerja.

Yang sering menjadi problem management adalah bagaimana menciptakan budaya kuat atau dengan kata lain bagaimana mengubah budaya lemah menjadi budaya kuat yang pada akhirnya akan mampu meningkatkan kinerja karyawan untuk tercapainya tujuan dari perusahaan atau organisasi. Budaya yang kuat sangat berpengaruh dalam peningkatkan 
INOBIS: Jurnal Inovasi Bisnis dan Manajemen Indonesia

Volume 1, Nomor 4, September 2018

Gendut Sukarno; Kustini

konsistensi seseorang dalam berperilaku. Dengan kata lain, budaya menjadi faktor penting meningkatkan kinerja atau performance karyawan dalam organisasi.

Berdasarkan uraian di atas, penulis akan mengkaji Pemicu Kinerja Karyawan Perbankkan melalui Knowledge Management dan Budaya Kerja.

\subsection{Rumusan Masalah}

Mengacu dari latar belakang di atas maka dirumuskan permasalahan sebagai berikut :

- Apakah Knowledge Management mempunyai kontribusi yang sangat berarti terhadap kinerja karyawan PT. Bank BJ?.

- Apakah Budaya Kerja mempunyai kontribusi yang sangat berarti terhadap kinerja karyawan PT. Bank BJ?

\subsection{Tujuan Penelitian}

Tujuan dari penelitian ini adalah sebagai berikut :

- Untuk mengkaji dan menganalisis kontribusi Knowledge Management terhadap kinerja karyawan PT.Bank BJ.

- Untuk mengkaji dan menganalisis kontribusi Budaya Kerja terhadap kinerja karyawan PT.Bank BJ.

\section{Landasan Teori dan Pengembangan Hipotesis}

\subsection{Landasan Teori}

\subsubsection{Kerangka Hubungan Variabel}

\subsubsection{Pengaruh Knowledge Management Terhadap Kinerja Karyawan}

Untuk menghasilkan kinerja karyawan yang baik dalam era pengetahuan saat ini, maka perusahaan membutuhkan pengelolaan atau manajemen yang dapat memperlakukan pengetahuan milik semua karyawan sebagai aset perusahaan. Knowledge management sendiri diterapkan oleh perusahaan untuk menjadi solusi dalam penyelesaian masalah mereka, dengan hasil akhir mencapai tujuan dan visi yang diharapkannya, yang diukur dari tiga komponen yaitu (Honeycutt, 2002) dalam Yusliana (2013), dengan 3 variabel yaitu personal knowledge, job procedure, dan technology. Komponen-komponen utama di dalam knowledge management tersebut membantu organisasi mencapai tujuan dan visi nya. Hal tersebut berhubungan dengan kinerja karyawan yang mana karyawan adalah penggerak utama sebuah perusahaan, sehingga ketika kinerja karyawan baik maka kinerja organisasi pun juga baik dan begitu sebaliknya, di dalam kinerja pun terdapat pengetahuan sebagai kemampuan yang dipenuhi. Maka dari itu, perusahaan perlu mengetahui sejauh nana knowledge management berperan dalam meningkatkan kinerja karyawan. Kinerja karyawan sendiri, diukur melalui 6 kriteria penilaian karyawan, yaitu: quality, quantity, timeliness, Cost effectiveness, need for supervision, dan interpersonal impact.

\subsubsection{Pengaruh Budaya Kerja Terhadap Kinerja Karyawan}

Terkait dengan dengan budaya kerja merupakan awal terbentuknya budaya perusahaan. Dalam hal ini budaya merupakan suatu ciri khas atau pembeda perusahaan yang 
INOBIS: Jurnal Inovasi Bisnis dan Manajemen Indonesia

Volume 1, Nomor 4, September 2018

Gendut Sukarno; Kustini

satu dengan perusahaan yang lain dalam menjalankan kegiatan operasionalnya. organisasi. Budaya kerja sering kali digunakan dalam melihat keunggulan dan gaya pimpinan perusahaan dalam menjalankan kegiatan operasional suatu perusahaan. Budaya sendiri merupakan suatu nilai-nilai yang dijadikan pedoman dalam bertingkah laku para karyawan dalam berorganisasi di lingkungan kerja sehari-hari. Budaya kerja yang kuat akan menciptakan suatu budaya perusahaan yang baik juga dan mencerminkan bahwa budaya tersebut telah memilki akar yang kuat dimana telah mampu dijiwai serta di aktualisasikan dalam kegiatan sehari-hari. Hal tersebut seperti nilai-nilai apa saja yang patut dimiliki, bagaimana perilaku setiap orang akan dapat mempengaruhi kerja mereka, kemudian falsafah yang dianutnya. Proses yang panjang yang terus menerus disempurnakan sesuai dengan tuntutan dan kemampuan sumber daya manusia itu sendiri sesuai dengan prinsip pedoman yang diakui.

Penerapan budaya yang didasarkan atas nilai-nilai yang dijunjung tinggi oleh perusahaan tersebut juga akan berdampak pada semakin menempatkan anggota perusahaan atau karyawan pada posisi mitra perusahaan tidak hanya sekedar faktor produksi yang siap dieksploitasi semaksimal mungkin dengan kata lain karyawan akan mendapatkan penghargaan yang lebih baik dari perusahaan.

Budaya kerja yang kuat akan berpengaruh positif pada kinerja bisnis karena dapat memberikan motivasi luar biasa pada karyawan. Dengan budaya organisasi yang kuat berarti karyawan-karyawan dalam organisasi mempunyai banyak nilai-nilai yang diyakini bersamasama. Hal ini menyebabkan lingkungan kerja yang nyaman, sehingga para karyawan merasa memperoleh dorongan kerja semakin kuat (John P Kotter dan James L. Heskett (1992). (Robinson, 2000).

\subsubsection{Kerangka Konseptual}

Berdasarkan dasar teori yang dilakukan pada bagian awal, selanjutnya dibentuk sebuah model penelitian. Model penelitian ini nantinya diharapkan akan dapat menjadi panduan bagi pemecahan masalah yang diajukan pada tulisan ini. Model pada penelitian yang merupakan kerangka konseptual ini menggambarkan pengaruh antara knowledge management dan budaya kerja terhadap kinerja karyawan.

Kerangka konseptual ini dapat dilihat pada gambar 1.1. berikut ini.

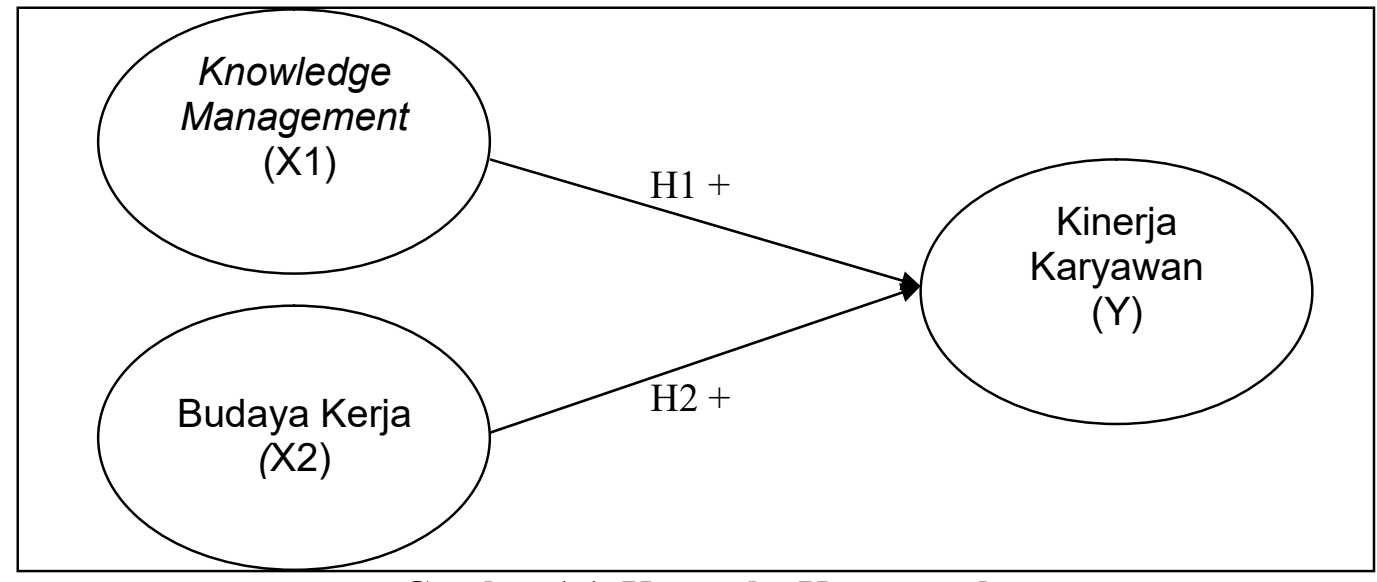

Gambar 1.1. Kerangka Konseptual 
INOBIS: Jurnal Inovasi Bisnis dan Manajemen Indonesia

Volume 1, Nomor 4, September 2018

Gendut Sukarno; Kustini

\section{Metode Penelitian}

\subsection{Definisi Operasional dan Pengukuran Variabel}

\subsubsection{Knowledge Management}

Knowledge management merupakan variabel Independent, atau sering disebut sebagai variabel stimulus, predictor, antecedent bahkan variabel bebas. Variabel Independent adalah merupakan variabel yang mempengaruhi atau menjadi sebab perubahannya atau timbulnya variabel dependent (terikat). Kategori yang termasuk knowledge management adalah :

a) Personal knowledge, (Carrillo et al., 2004) menyebutkan bahwa personal knowledge adalah pengetahuan yang diperoleh karyawan berupa pengalaman

b) Job procedure, (Carrillo et al., 2004) menyebutkan bahwa Job procedure adalah tanggung jawab atau tugas yang harus dijalankan oleh karyawan

c) Technology, (Carrillo et al., 2004) menyebutkan bahwa Technology adalah media penyebaran informasi melalui sarana intranet yang digunakan untuk mendukung tiap kegiatan kerja di dalam perusahaan.

\subsubsection{Budaya Kerja}

Budaya Kerja merupakan derajat kekuatan suatu budaya pada instansi Perbankkan, baik yang bersifat eksplisit (yang ditanamkan oleh manajemen) dalam bentuk peraturan perusahaan atau aturan-aturan kerja maupun yang bersifat implisit, yang terefleksikan dalam perilaku atau tindakan manajemen, pimpinan maupun karyawan sendiri yang dapat mempengaruhi perilaku kerja karyawan, (Prasetyo, 2011) : Budaya eksplisit : Kebijakan Perusahaan, Keyakinan pada peraturan, Ketaatan pada peraturan, Keterbukaan terhadap pekerjaan. Budaya implisit : Keinginan Untuk Maju, Bekerja secara teliti, Percaya diri sendiri, Semangat kerjasama antar rekan kerja, Hubungan yang terjalin antara atasan dengan karyawan

\subsubsection{Kinerja Karyawan}

Kinerja Karyawan merupakan hasil kerja secara kualitas dan kuantitas yang dicapai oleh seseorang karyawan dalam melaksanakan tugasnya sesuai dengan tanggung jawab yang diberikan kepadanya. Indikator impirik pada penelitiannya berupa:

1. Quality, 2. Quantity, 3. Timeliness, 4. Cost effectiveness, 5. Need for supervision, 6. Interpersonal Impact.

\subsection{Populasi dan Sampel}

\subsubsection{Populasi}

Populasi dalam penelitian ini adalah seluruh karyawan PT. Bank BJ. di Surabaya. Adapun sampel dalam penelitian ini ada karyawan PT. Bank BJ. Sebanyak 47 karyawab sebagai responden. 
INOBIS: Jurnal Inovasi Bisnis dan Manajemen Indonesia

Volume 1, Nomor 4, September 2018

Gendut Sukarno; Kustini

\subsection{Teknik Analisis Data}

Teknik analisis yang digunakan dalam penelitian adalah Partial Least Square (PLS), menurut Wold merupakan metode analisis yang powerful oleh karena tidak didasarkan banyak asumsi. PLS sebagai teknik analisis data mempunyai keunggulan tersendiri diantaranya : data tidak harus berdistribusi normal multivariate (indikator dengan skala kategori, ordinal, interval sampai rasio dapat digunakan pada model yang sama). Selain itu ukuran sampel tidak harus besar. Walaupun PLS digunakan untuk mengkonfirmasi teori, tetapi dapat juga digunakan untuk menjelaskan ada atau tidaknya hubungan antara variabel laten. Kelebihan lain, PLS dapat menganalisis sekaligus konstruk yang dibentuk dengan indikator refleksif dan indikator formatif dan hal ini tidak mungkin dijalankan dalam Structural Equation Model (SEM) karena akan terjadi unidentified model.

\section{Hasil dan Pembahasan}

\subsection{Hasil Penelitian}

\subsubsection{Evaluasi Model Pengukuran (Outner Model)}

Tabel 1.1.

Uji Validitas Indikator Reflektf

\begin{tabular}{|c|c|c|c|}
\hline Variabel /Dimensi & Indikator & $\begin{array}{c}\text { Loading } \\
\text { Factor }\end{array}$ & AVE \\
\hline $\begin{array}{c}\text { Knowledge } \\
\text { Management (X1) }\end{array}$ & & & 0,580542 \\
\hline \multirow{5}{*}{$\begin{array}{c}\text { Personal Knowledge } \\
\text { (X1.1) }\end{array}$} & $\mathrm{X} 1.1 .1$ & 0,844332 & \multirow{5}{*}{0,530368} \\
\hline & $\mathrm{X} 1.1 .2$ & 0,604437 & \\
\hline & $\mathrm{X} 1.1 .3$ & 0,655591 & \\
\hline & X1.1.4 & 0.498601 & \\
\hline & $\mathrm{X} 1.1 .5$ & 0,628647 & \\
\hline \multirow{4}{*}{ Job Procedure (X1.2) } & $\mathrm{X} 1.2 .1$ & 0,816533 & \multirow{4}{*}{0,675764} \\
\hline & $\mathrm{X} 1.2 .2$ & 0,798216 & \\
\hline & $\mathrm{X} 1.2 .3$ & 0,815248 & \\
\hline & $\mathrm{X} 1.2 .4$ & 0,857061 & \\
\hline \multirow{4}{*}{ Technology (X1.3) } & $\mathrm{X} 1.3 .1$ & 0,810248 & \multirow{4}{*}{0,697398} \\
\hline & $\mathrm{X} 1.3 .2$ & 0,895029 & \\
\hline & $\mathrm{X} 1.3 .3$ & 0,818334 & \\
\hline & $\mathrm{X} 1.3 .4$ & 0,813845 & \\
\hline \multirow{9}{*}{ Budaya Kerja (X2) } & $\mathrm{X} 2.1$ & 0,836618 & \multirow{9}{*}{0,551710} \\
\hline & $\mathrm{X} 2.2$ & 0,707878 & \\
\hline & $\mathrm{X} 2.3$ & 0,701281 & \\
\hline & $\mathrm{X} 2.4$ & 0,826969 & \\
\hline & $\mathrm{X} 2.5$ & 0,603963 & \\
\hline & $\mathrm{X} 2.6$ & 0,550176 & \\
\hline & $\mathrm{X} 2.7$ & 0,652494 & \\
\hline & $\mathrm{X} 2.8$ & 0,651613 & \\
\hline & $\mathrm{X} 2.9$ & 0,413381 & \\
\hline
\end{tabular}


INOBIS: Jurnal Inovasi Bisnis dan Manajemen Indonesia

Volume 1, Nomor 4, September 2018

Gendut Sukarno; Kustini

\begin{tabular}{|l|l|c|c|}
\hline \multirow{5}{*}{ Kinerja Karyawan (Y) } & Y1 & $-0,012016$ & \multirow{4}{*}{0} \\
\cline { 2 - 3 } & Y2 & 0,580028 & \multirow{4}{*}{0,506635} \\
\cline { 2 - 3 } & Y3 & 0,771958 & 0,417743 \\
\cline { 2 - 3 } & Y4 & 0,762821 & \\
\cline { 2 - 3 } & Y5 & $-0,866552$ & \\
\hline & Y6 & \\
\hline
\end{tabular}

Sumber : Output analisis smartPLS

Uji validitas indikator reflektif dapat dikatakan valid apabila nilai loading factor $\geq$ 0,5. Uji validitas variabel laten pada indikator reflektif dapat dilihat dari nilai Avarage variance extracted (AVE) untuk setiap konstruk (variabel). Disyaratkan model yang baik apabila nilai AVE masing-masing konstruk $>0,5$. Model hubungan dimensi dengan indikator pada variabel knowledge management adalah bentuk reflektif, begitu juga hubungan indikator dengan variable pada variable budaya kerja dan kinerja karyawan adalah reflektif, maka cara menilai model pengukurannya adalah dengan melihat nilai factor loading pada tabel outer loading. Hasil output smartPLS analisis validitas indikator reflektif adalah sebagai berikut.

Berdasarkan table 1.1, menunjukkan nilai factor loading indicator seluruh variabel Knowledge Management lebih besar dari 0,50, hal tersebut menjadi pengukur/indikator variabel Knowledge Management kecuali indicator Personal Knowledge X1.1.4. Demikian juga seluruh indikator variabel budaya kerja lebih besar dari 0,50 , sehingga indikator tersebut menjadi pengukur/indikator variabel budaya kerja, kecuali indikator budaya kerja X2.9. Demikian juga kinerja karyawan semua nilai factor loadingnya lebih besar dari 0,50 , sehingga indikator yang dikonstruk dapat dikatakan tepat menjadi pengukur/indikator variabel kinerja karyawan, kecuali indikator Y1 dan Y4.

Adapun hasil pengujian nilai AVE untuk seluruh dimensi dan indikator memiliki nilai lebih besar dari 0,5, sehingga dimensi/variabel tersebut dapat dikatakan valid. Dari ketiga dimensi tersebut yang paling valid adalah dimensi technology dengan nilai AVE 0,697398 .

Nilai Average Variance Extracted (AVE) pada pembentukan variabel laten dari varians indikatornya yaitu lebih besar dari 0,50 , sehingga dapat dikatakan valid. Secara keseluruhan hasil estimasi telah memenuhi Convergen validity dan valisitas baik.

Tabel 1.2.

Uji Reliabilitas (Composite Reliability)

\begin{tabular}{|l|c|c|c|}
\hline \multicolumn{1}{|c|}{ Variabel/Dimensi } & $\begin{array}{l}\text { Composite } \\
\text { Reliability }\end{array}$ & Kriteria & Ket. \\
\hline $\begin{array}{l}\text { Knowledge Management } \\
(\mathrm{X} 1)\end{array}$ & 0,881034 & $>0,70$ & Reliabel \\
\hline Personal Knowledge (X1.1) & 0,785715 & $>0,70$ & Reliabel \\
\hline Job Procedure (X1.2) & 0,892830 & $>0,70$ & Reliabel \\
\hline Technology (X1.3) & 0,901983 & $>0,70$ & Reliabel \\
\hline Budaya Kerja (X2) & 0,877462 & $>0,70$ & Reliabel \\
\hline Kinerja Karyawan (Y) & 0,734518 & $>0,70$ & Reliabel \\
\hline
\end{tabular}

Sumber: Output analisis smartPLS, Lampiran 3

Pada pengujian reliabilitas berbeda dengan uji validitas, bila uji validitas ada untuk indikator dan variabel laten, sementara itu uji reliabilitas hanya ada untuk variabel laten saja. Uji reliabilitas dilakukan untuk menunjukkan ketelitian data dari kuesioner yang digunakan. 
INOBIS: Jurnal Inovasi Bisnis dan Manajemen Indonesia

Volume 1, Nomor 4, September 2018

Gendut Sukarno; Kustini

Uji reliabilitas dalam penelitian ini, statistik ujinya menggunakan composite reliability. Kriteria pengambilan keputusannya yaitu dapat dikatakan reliable apabila variabel mempunyai nilai composite reliability lebih besar dari 0,70. Hasil output analisis PLS sebagai berikut.

Berdasarkan hasil table 4.11, dapat disimpulkan bahwa konstruk dimensi Personal Knowledge, Job Procedure dan Technology serta variabel Knowledge Management, variabel Budaya Kerja dan Kinerja Karyawan memiliki nilai composite reliability lebih besar dari 0,7, sehingga dimensi/variabel tersebut dapat dikatakan reliabel. Artinya, dengan nilai composite reliability diatas 0,70 maka indikator pada dimensi Personal Knowledge, Job Procedure dan Technology serta variabel Budaya Kerja dan Kinerja Karyawan disebut konsisten dalam mengukur variabel latennya.

\subsubsection{Pengukuran Inner Model}

Tabel 1.3.

Nilai R-square

\begin{tabular}{|l|c|}
\hline \multicolumn{1}{|c|}{ Variabel/Dimensi } & R Square \\
\hline Knowledge Management (X1) & \\
\hline Budaya Kerja (X2) & 0,169213 \\
\hline Kinerja Karyawan (Y) & \\
\hline
\end{tabular}

Sumber: Output analisis smartPLS, Lampiran 3

Penentuan nilai koefisien determinasi total ditunjukkan dengan nilai $Q$-Square predictive relevance $\left(\mathrm{Q}^{2}\right)=1-\left(1-\mathrm{R} 1^{2}\right)=1-(1-0,1692)=0,1692$. Hal ini dapat diinterpretasikan bahwa model mampu menjelaskan fenomena / masalah Kinerja Karyawan sebesar 16,92 \%. Sedangkan sisanya (83,08\%) dijelaskan oleh variabel lain (selain Knowledge Management dan Budaya Kerja, seperti kepemimpinan, kualitas pelayanan, suku bunga, variasi produk, kompensasi dan lain-lain) yang belum masuk ke dalam model dan error.

Selain itu, berkaitan dengan Knowledge Management, karyawan telah bekerja sesuai dengan aturan kerja perusahaan atau Standar Operasional Perusahaan (SOP) dan Buku Pedoman Pelaksana (BPP) dengan baik yang ada di Bank BJ, sehingga tidak berpengaruh terhadap kinerja karyawan. Berkaitan dengan Budaya Kerja, indikator-indikator yang ada pada budaya kerja yaitu kebijakan perusahaan, keyakinan pada peraturan, ketaatan pada peraturan, keterbukaan terhadap pekerjaan, keinginan untuk maju, bekerja secara teliti, percaya diri sendiri, semangat kerjasama antar rekan kerja, hubungan yang terjalin antara atasan dengan karyawan tidak mampu memberikan kontribusi terhadap kinerja karyawan.

Model hubungan variabel dengan indikator yang dikonstruk pada penelitian ini dapat dilihat dari hasil calculate model struktural berikut. 
INOBIS: Jurnal Inovasi Bisnis dan Manajemen Indonesia Volume 1, Nomor 4, September 2018

Gendut Sukarno; Kustini

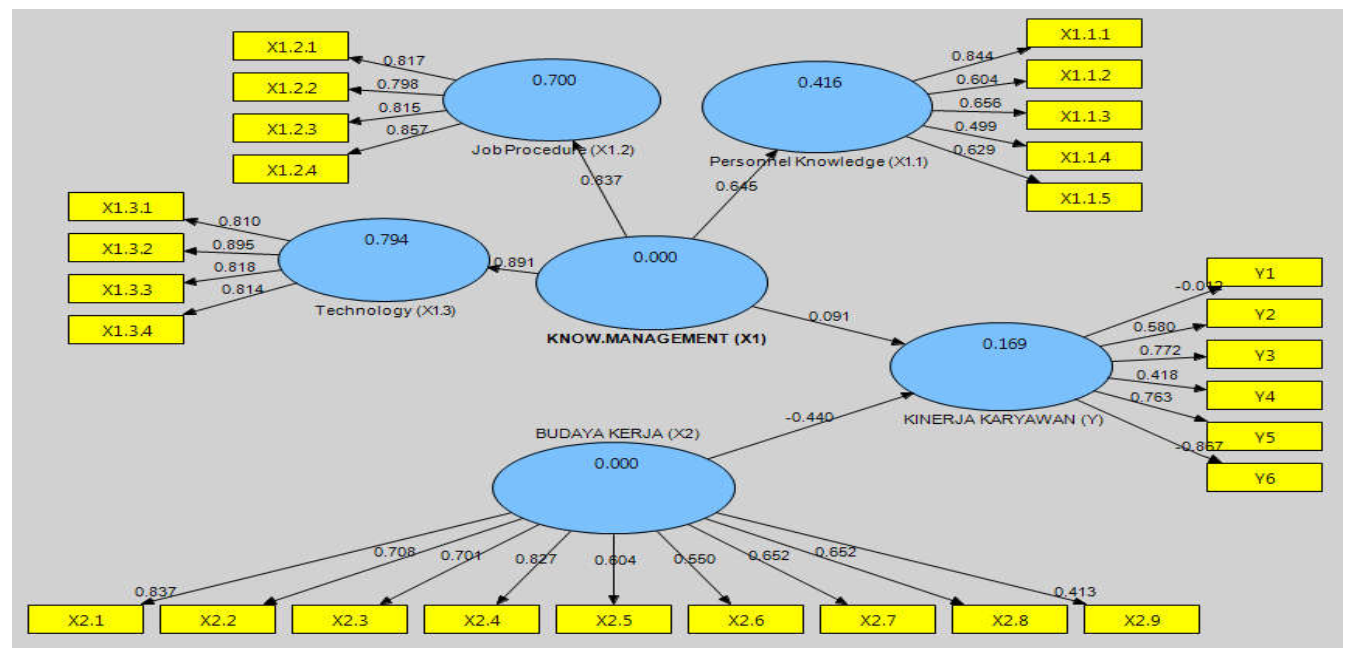

Gambar 1.2 Model Struktural Output SmartPLS

Sumber: Output analisis smartPLS, Lampiran 3

Berdasarkan gambar 1.2., maka dapat diklasifikasikan bahwa pengaruh hubungan variabel laten eksogen terhadap variabel laten endogen (kinerja karyawan) sebagai pengujian hipotesis dalam penelitian ini dapat dilihat pada path coeficient parameter pada table berikut :

Tabel 1.4.

Path Coefficients (Mean, STDEV, T-Values)

\begin{tabular}{|l|l|c|c|l|l|}
\hline Variabel & $\begin{array}{l}\text { Koefisien } \\
\text { Path (O) }\end{array}$ & $\begin{array}{c}\text { Standard } \\
\text { Error }\end{array}$ & $\begin{array}{c}\text { T } \\
\text { Statistic } \\
\text { S }\end{array}$ & $\begin{array}{l}\text { Kriteri } \\
\mathbf{a}\end{array}$ & Keputusan \\
\hline $\begin{array}{l}\text { Knowledge } \\
\text { Management (X1) }-> \\
\text { Kinerja Karyawan (Y) }\end{array}$ & 0,091327 & 0,037619 & 2,427682 & $>1,645$ & $\begin{array}{l}\text { Berpengaruh } \\
\text { Signifikan }\end{array}$ \\
\hline $\begin{array}{l}\text { Budaya Kerja (X2) -) } \\
\text { Kinerja Karyawan (Y) }\end{array}$ & $-0,440402$ & 0,572910 & 0,768710 & $<1,645$ & $\begin{array}{l}\text { Berpengaruh } \\
\text { Non } \\
\text { Signifikan }\end{array}$ \\
\hline
\end{tabular}

Sumber: Output analisis smartPLS, Lampiran 3

Berdasarkan table 1.4. diatas, maka dapat diinterpretasikan sebagai berikut.

1. Knowledge management berpengaruh signifikan positif terhadap kinerja karyawan PT. Bank BJ.

2. Budaya kerja berpengaruh non signifikan terhadap kinerja karyawan PT.Bank BJ.

3. Variabel yang dominan mempengaruhi langsung terhadap kinerja karyawan PT. Bank BJ yaitu variabel knowledge management.

\section{Pembahasan}

\subsection{Pengaruh Knowledge Management terhadap Kinerja Karyawan Bank BJ}

Berdasarkan hasil olah data ditemukan bahwa knowledge management berpengaruh positif signifikan terhadap kinerja karyawan PT. Bank BJ. Kekuatan knowledge management tersebut diperkuat oleh kekuatan dari masing-masing dimensi Knowledge management : 
INOBIS: Jurnal Inovasi Bisnis dan Manajemen Indonesia

Volume 1, Nomor 4, September 2018

Gendut Sukarno; Kustini

personal knowledge, job procedure, dan technology seluruhnya memenuhi kriteria baik dilihat dari loading factor maupun Composite Reliability. Demikian juga jika dilihat dari indicator dari ke 3 dimensi di atas, sebagian besar mempunyai indicator yang memenuhi kriteria. Hal tersebut mengindikasikan bahwa knowledge management yang ada pada PT. Bank BJ sangat kokoh, baik kekohan dalam hal personal knowledge, job procedure, dan technology. Hal tersebut sesuai dengan hasil penelitian Natalia et al (2011) yang menjelasakan personal knowledge, job procedur dan technology dalam penelitiannya berpengaruh langsung signifikan terhadap kinerja karyawan di Hotel Nirwana Bojonegoro. Hal senada juga diperkuat oleh pendapat Malhotra, Y. (2000), bahwa knowledge management (personal knowledge, job procedure dan technology) berpengaruh secara signifikan terhadap kinerja karyawan.

Berdasarkan persepsi responden dapat dijelaskan bahwa indikator dari dimensi personal knowledge yang memiliki frekuensi dominan yaitu faktor pengalaman yang diperoleh memperkaya pengetahuan. Hal ini menunjukkan bahwa saat ini responden lebih memperhatikan pengalaman yang diperoleh memperkaya pengetahuan yang ditunjukkan oleh karyawan sebagai tolak ukur knowledge management. Indikator dari dimensi job procedure yang memiliki frekuensi dominan yaitu SOP sebagai alat komunikasi bagi manajemen dengan karyawannya dan SOP sebagai alat untuk melaksanakan pelatihan bagi karyawan lama maupun karyawan baru. Hal ini menunjukkan bahwa pada saat ini responden lebih memperhatikan SOP dapat membantu karyawan dalam berkomunikasi dengan atasan serta dapat dijadikan acuan oleh atasan dalam memberikan pelatihan terhadap karyawan.

Indikator dari dimensi technology yang memiliki frekuensi dominan yaitu pada technology membantu proses kerja karyawan. Hal ini menunjukkan bahwa bahwa pada saat ini responden lebih memperhatikan technology yang baik sangat membantu proses kerja karyawan dan mengingat persepsi responden yang dominan terhadap variabel kinerja karyawan yaitu pada technology dapat meningkatkan efisiensi kerja baik dari segi waktu dan biaya.

Hal tersebut dapat ditarik kesimpulan bahwa knowledge management dengan pengalaman yang dimiliki, pemahaman Standart Operation Procedur serta technology yang baik akan berpengaruh pada kinerja karyawan.

\subsection{Pengaruh Budaya Kerja terhadap Kinerja Karyawan PT. Bank BJ.}

Berdasarkan hasil olah data ditemukan bahwa budaya kerja berpengaruh tidak signifikan terhadap kinerja karyawan PT. Bank BJ. Fenomena di atas disebabkan indikatorindikator yang ada pada budaya kerja baik ditinjau dari loading factor maupun AVE sebagian besar mempunyai nilai disekitaran 0.50 hingga 0.60 . Fenomena demikian mengindikasikan kekuatan budaya kerja yang tidak terlalu kuat atau cenderung lemah. Karyawan Bank BJ menganggap bahwa budaya kerja sudah seharusnya ada, wajib dan karyawan juga menganggap bahwa budaya kerja merupakan hal yang sudah lumrah dan seharusnya ada di dalam perusahaan. Karyawan telah bekerja sesuai dengan aturan kerja perusahaan atau Standar Operasional Perusahaan (SOP) dan Buku Pedoman Pelaksana (BPP) dengan baik yang ada di PT. Bank BJ, sehingga budaya kerja tidak berpengaruh terhadap kinerja karyawan. Budaya kerja sudah terbentuk saat masa pendidikan awal masuk Bank BJ, saat pendidikan kesamaptaan, adanya pendidikan SDP (Development Program), MDP (Manager Development Program) dan EDP (Executive Development Program) bagi penyelia hingga pemimpin cabang. Temuan ini sesuai dengan yang dilakukan John P Kotter dan James L. Heskett (1992) dalam bukunya Budaya Korporat dan Kinerja menyatakan meski telah 
INOBIS: Jurnal Inovasi Bisnis dan Manajemen Indonesia

Volume 1, Nomor 4, September 2018

Gendut Sukarno; Kustini

diyakini secara luas bahwa budaya yang kuat menciptakan kinerja yang unggul namun pengalaman di 200 perusahaan yang diteliti tidak mendukung teori ini. Hal yang sama juga ditemukan dalam penelitian yang dilakukan oleh Jagarin Pane dan Sih Darmi Astuti, 2009, bahwa Budaya Organisasi tidak berpengaruh terhadap Kinerja Karyawan Telkom Regional IV di Semarang.

\section{Simpulan}

Berdasarkan hasil pembahasan di atas, maka dapat ditarik kesimpulan sebagai berikut:

1. Knowledge management mampu memberikan kontribusi terhadap kinerja karyawan PT. Bank BJ.

2. Budaya kerja tidak mampu memberikan kontribusi terhadap kinerja karyawan PT. Bank BJ.

\section{Daftar Referensi}

Triguno. 1997. Budaya Kerja. Jakarta : Penerbit PT. Golden T. Press

Honeycutt, J. (2005). Knowledge management strategies; Strategi manajemen pengetahuan. Jakarta: PT. Elex Media Komputindo.

Kotter, John P. \& James L. Heskett. 1992. Corporate Culture dan Performance Free Press, New York, NY.

Carrillo, P., Robinson, H., Al-Ghassani, A., Anumba, C. (2004). Knowledge management in UK construction: Strategies, resources and barriers. Project Management Journal, 35, (1), p. 46.

Malhotra, Y. (2000). Knowledge management for [e-] business performance information strategy. The Executive Journal, 16, (4), pp. 5-16.

Jagarin Pane dan Sih Darmi Astuti, 2009. Pengaruh Budaya Organisasi, Kepemimpinan Transformasional, Dan Kompensasi Terhadap Kinerja Karyawan (Studi Pada Kantor Telkom Divre IV Di Semarang), TEMA Vol 6 Edisi 1, Maret 2009 hal 67 -85 